\title{
Flux Measurements in Trees: Methodological Approach and Application to Vineyards
}

\author{
Gianfranco Rana*1, Francesca De Lorenzi ${ }^{2}$ \\ ${ }^{1}$ Consiglio per la Ricerca e Sperimentazione in Agricoltura - Unità di Ricerca \\ per $i$ Sistemi Colturali degli Ambienti Caldo-Aridi \\ Via C. Ulpiani 5, 70125 Bari, Italy \\ ${ }^{2}$ Consiglio Nazionale delle Ricerche - Istituto per i Sistemi Agricoli e Forestali del Mediterraneo \\ Via Patacca 85, 80156 Ercolano (NA), Italy
}

Received: 7 January 2008. Accepted 10 February 2008.

\begin{abstract}
In this paper a review of two sap flow methods for measuring the transpiration in vineyards is presented. The objective of this work is to examine the potential of detecting transpiration in trees in response to environmental stresses, particularly the high concentration of ozone $\left(\mathrm{O}_{3}\right)$ in troposphere. The methods described are the stem heat balance and the thermal dissipation probe; advantages and disadvantages of each method are detailed. Applications of both techniques are shown, in two large commercial vineyards in Southern Italy (Apulia and Sicily), submitted to semi-arid climate. Sap flow techniques allow to measure transpiration at plant scale and an upscaling procedure is necessary to calculate the transpiration at the whole stand level. Here a general technique to link the value of transpiration at plant level to the canopy value is presented, based on experimental relationships between transpiration and biometric characteristics of the trees. In both vineyards transpiration measured by sap flow methods compares well with evapotranspiration measured by micrometeorological techniques at canopy scale. Moreover soil evaporation component has been quantified. In conclusion, comments about the suitability of the sap flow methods for studying the interactions between trees and ozone are given.
\end{abstract}

Key-words: transpiration, sap flow, stem heat balance, thermal dissipation probe, upscaling.

\section{Introduction}

The research on the exchange of trace gases between cropped surfaces and the atmosphere is a priority, due to the rapid increase in the last decades of the concentration of these minority atmosphere compounds, caused by human activities. In particular, the increase of ozone $\left(\mathrm{O}_{3}\right)$ concentration in troposphere, mostly in the surface layer of air, is a priority issue to be deepened, mainly with respect to its effects on plant health (e.g. Sandermann, 1996). Plants in Mediterranean environments are prone to $\mathrm{O}_{3}$ injury; in fact Southern Europe is affected by high $\mathrm{O}_{3}$ concentration (Fagnano, 1995; Ferretti et al., 2006) and detailed analysis of how and when agricultural crops interact with $\mathrm{O}_{3}$ have recently been published for semi-arid Mediterranean environments (Postiglione et al., 2000;
Forlani et al., 2005; Fagnano and Merola, 2007; Bou Jaoudè et al., 2008a; 2008b).

Few researches on $\mathrm{O}_{3}$ exchange have been carried out in orchards, since measurements of energy and mass exchanges in these discontinuous crops by micrometeorological techniques are quite complex (Arya, 2001), particularly in Mediterranean region, where the trees are submitted to arid and semi-arid climates (Rana and Katerji, 2000). Mitic et al. (1999) measured the $\mathrm{O}_{3}$ flux over a grape canopy by eddy covariance technique, showing that, under atmospheric unstable conditions, turbulent structures simultaneously transport $\mathrm{CO}_{2}, \mathrm{H}_{2} \mathrm{O}$, ozone and heat, and that under stable conditions the interpretation of results is much more complex.

Vineyards are one of the most important crops in the Mediterranean basin and are con-

* Corresponding Author: Tel.: +39 080 5475026. E-mail address: gianfranco.rana@entecra.it 
sidered sensible to high $\mathrm{O}_{3}$ concentration levels (Shertz et al., 1980; Weinstein, 1984; Fumagalli et al., 2001). Soja et al. (1997) demonstrated that grapevine grown in Austria reduced its yield and sugar content in grapes when submitted to high $\mathrm{O}_{3}$ concentration levels.

The atmospheric $\mathrm{O}_{3}$ has phytotoxical effects on plants, dependent on the stomatal uptake and the amount of molecular diffusion of ozone into the inner tissues of the leaves. Therefore stomatal regulation and $\mathrm{O}_{3}$ concentration above the crop play a major role (Musselman and Massman, 1999). In particular, Grantz et al. (1995) analysed the stomatal and non-stomatal ozone deposition in grapevines grown in San Joaquin Valley of California; they concluded that canopy conductance to water vapour may be used effectively to predict ozone deposition to physiologically active vegetated surfaces.

Measurements of canopy conductance can therefore provide acceptable estimates of conductance for ozone. Water vapour conductance at canopy level can be inferred from measurements at leaf level, but many representative measurements are required and continuous monitoring is not normally possible. Quite recently, techniques for measuring sap flow have been applied for measuring transpiration in orchards (Green et al., 1989; Tognetti et al., 2004; Nadezhdina et al., 2007; Fernandez et al., 2007). These techniques allow continuous monitoring of whole-plant transpiration, and it is now possible to obtain continuous measurements of canopy water vapour conductance from wholeplant sap flow and micrometeorological variables. Canopy conductance has been successfully derived by means of sap flow measurements in grapevines by Lu et al. (2003) and in poplar trees by Zhang et al. (1997), among others.

Sap flow technique could therefore be promising and suitable for specific studies on $\mathrm{O}_{3}$ exchange between trees and the atmosphere (Wieser et al., 2003). Moreover, combining eddy covariance and sap flow techniques allows to separate the evaporative water loss of the plant to that of the soil. This is a step forward in distinguishing "stomatal flux" component of the "surface flux" (as defined by Musselman et al., 2006) of ozone deposition in orchards.

In the present paper a description of two sap flow techniques is given and the results of their application to vineyards are shown, including an example of procedure to upscale the fluxes from organ to plant and to field scale.

\section{Sap flow techniques, upscaling and experi- mental applications}

Sap flow is closely linked to plant transpiration and can be calculated by methods that use heat energy as a tracer. Few applications of sap flow measurements are available in vineyards: the techniques used are mainly (i) Granier's Thermal Dissipation Probes (TDP) (Braun and Schmid, 1999; Lu et al., 2003) and (ii) Stem Heat Balance technique (SHB) (Trambouze et al., 1998; De Lorenzi et al., 2002). An application of heat pulse technique to vines is shown e.g. in Yunusa et al. (2004).

Here theory and application of SHB and TDP methods are described in detail, also referring to the experimental work carried out in vineyards by the authors.

\subsection{The Stem Heat Balance method (SHB)}

This method has been first introduced by Sakuratani (1981). A constant heat is supplied to the stem of the plant, and the balance can be written:

$$
Q_{i}=Q_{v}+Q_{r}+Q_{f}
$$

where $Q_{i}(\mathrm{~W})$ is a steady, known amount of heat applied to a segment of the stem. The heat input is balanced by heat fluxes out of the segment: conduction along the stem $\left(Q_{v}, \mathrm{~W}\right)$ and outward through the gauge $\left(Q_{r}, \mathrm{~W}\right)$, convection in the transpiration stream $\left(Q_{f}, \mathrm{~W}\right)$. Conductive fluxes are estimated from thermal conductivities - known or measured - and temperature gradients measured by thermocouples placed against the stem. Subtraction of the conductive fluxes from the known heat input yields the convection term $Q_{f} Q_{f}$ is divided by the heat capacity of sap $\left(c_{w}, \mathrm{~J} \mathrm{~g} \mathrm{~g}^{-1} \mathrm{~K}^{-1}\right)$ and by the temperature gradient across the heater $(\Delta T, \mathrm{~K})$ to calculate the mass flow rate of the sap $\left(F_{S H B}, \mathrm{~g} \mathrm{~s}^{-1}\right)$ :

$$
F_{S H B}=\frac{Q_{f}}{c_{w} \cdot \Delta T}
$$

Some assumptions are implicit in the relationships described by eq. (1) and (2): (i) the temperature gradients measured at the stem 
surface are representative of the gradients in the whole stem section (Sakuratani, 1981); (ii) heat storage in the stem is negligible in relation to the heat applied, therefore steady state conditions exist within the stem segment (Grime et al., 1995). The heat storage term is thus omitted on the right side of eq. (1); (iii) the term $\Delta T$ is solely a consequence of the heat applied to the stem through the heater, i.e. the ambient does not create temperature gradients within the thermocouples' area (Gutierrez et al., 1994).

These conditions are assumed to be met by Baker and van Bavel (1987) and many other authors that used the SHB technique. However, some published studies describe inaccuracies in the SHB measurements, and explain them by the inapplicability of one or more of the above mentioned assumptions. For instance, the mathematical analysis of Baker and Nieber (1989) indicates, at high flows, an alteration of the temperature distribution in the stem and gauge. As a consequence temperatures measured at stem surface may not represent the thermal gradients of the heated volume. Grime et al. (1995) show the advantage of including the heat storage term in sap flow measurements, especially at low flow rates. Gutierrez et al. (1994) detect stem temperature differentials across the heater even in the absence of power applied. Therefore, any application of the SHB technique should investigate if these critical assumptions are met.

In spite of the wide use of SHB technique, the accuracy of the method is still a matter of discussion. Most published studies report a relative error of about $\pm 10 \%$; although some experimental researches (e.g. Cohen et al., 1993) indicate varying results, in dependence of the species and of the experimental conditions. The most comprehensive study on the performance of the SHB technique has been conducted by Kjelgaard et al. (1997). Their statistical analysis tests SHB gauges with three field crops and results show relative error ranging from $\pm 5.6 \%$ to $\pm 17.6 \%$.

\subsection{The Thermal Dissipation Probe method (TDP)}

This method was first introduced by Granier (1985). The TDP technique measures the difference in temperature $(\Delta T)$ between a heated upper needle and a lower reference needle when placed in the conducting xylem of a woody stem. Using a regulated, known power input, the stem is constantly heated up to a thermic level approximately $15{ }^{\circ} \mathrm{C}$ above air temperature. As sap flows past the two needles, the lower reference needle records the reference sap temperature and the upper heated needle is cooled. If rapid sap flow occurs the difference in temperature between the two needles is low as the heat input from the upper needle is being quickly dissipated. When sap flow is low or close to zero a maximum difference in temperature $\left(\Delta T_{\max }\right)$ is recorded because heat is no longer dissipated by convection.

Granier's equation then uses the measured $\Delta T$ and $\Delta T_{\max }$ values to calculate sap velocity, and a dimensionless "flow index" $(K)$ is calculated from the measured temperature difference and the maximum value, occurring at zero flow rate, as:

$$
K=\frac{\Delta T_{\max }-\Delta T}{\Delta T}
$$

Granier established an empirical relation between the value of $K$ and the actual sap flow density $\left(F_{d}, \mathrm{~g} \mathrm{~m}^{-2} \mathrm{~s}^{-1}\right)$, using trunk sections of 40$50 \mathrm{~mm}$ in diameter; the exponential relation did not differ significantly within a number of common tree species and reads:

$$
F_{d}=118.99 K^{1.231}
$$

The sap flux density has to be extrapolated to the whole cross-sectional area of the sapwood (active water-conducting xylem), therefore total sap flow of the tree $\left(F_{T D P}, \mathrm{~g} \mathrm{~s}^{-1}\right)$ is calculated as the product of $F_{d}$ and the area of the cross-section of the sapwood at the level of heated probe $\left(A_{s w}, \mathrm{~m}^{2}\right)$ :

$$
F_{T D P}=F_{d} A_{s w}
$$

Since determination of $\Delta T_{\max }$ is fundamental for the calculation of $F_{T D P}$, precautions must be taken in its evaluation. In fact, although $\Delta T_{\max }$ can theoretically be defined as $\Delta T$ at $F_{d}=0$, that usually occurs predawn, many factors prevent the occurrence of the zero flow rate ( $\mathrm{Lu}$ et al., 2004). Among these factors the most important are: i) the night-time water movement for new growth, ii) slow restoration of the tree's internal water storage during prolonged drought (Goldstein et al., 1998) typical of the Mediterranean region, iii) water loss from the canopy 
due to high vapour pressure deficit and high wind speed (Snyder et al., 2003). Non-zero flow during the night affects the determination of the sap flow by underestimating the true $\Delta T_{\max }$ required in the calculation of the sap flux, thus underestimating $F_{d}$. Furthermore, according to Granier (1987), $\Delta T_{\max }$ should be determined separately for each sensor because it is a compound result of the specific probe-tree system.

TDP estimates of water use have usually compared well with estimates from other sap flow techniques (Köstner et al., 1998) or independent micrometeorological methods (Granier et al. 1996). In potted vines Braun and Schmid (1999) measured a maximum relative error of $\pm 10 \%$ for daily sap flow values. The detailed description of the sensors used for the application of both techniques here presented can be found, e.g., in Smith and Allen (1996).

\subsection{The upscaling of transpiration in vineyards}

For determining transpiration $(T)$ at the stand level sap flow measurements have to be scaled up within trees, and from the plant to the field scale. This is possible only if the canopy structure, the frequency distribution and the spatial variability of the biometric plants' parameters (e.g. branch and stem diameter, leaf area, sapwood area, tree domain) are accurately known. For uniform stands scaling up can be based on simple biometric parameters analysis.

In trees, SHB measurements can be taken in a series of branches (Zhang et al., 1997; Rana et al., 2005); in fact, the assumption implied in the SHB method are more easily met in smaller structures, like branches, than in trunks. Application of biometric parameters available at the branch and entire tree level is a prerequisite for this approach. In the present paper, it will be shown how, in vineyards, transpiration determined in shoots can be extended to the whole plant by means of leaf area (De Lorenzi et al., 2002). Similarly, transpiration rate calculated per unit leaf area has been used in scaling up sap flow data from plant to stand level by means of leaf area estimates (Zhang et al., 1997).

We have previously described how, in TDP method, flux density at the probe level is integrated to the whole water conductive area. The use of eq. (5) implies that measurements of flux density with Granier probes account for the ra- dial variation of $F_{d}$ and, when a single probe per tree is used, circumferential variations are not substantial. Lu (1997) and Clearwater et al. (1999) showed that the estimates of sap velocity from Granier probes were relatively insensitive to moderate radial variation in $F_{d}$ in coniferous and diffuse-porous trees. We can assume that, in the rather uniform ring-porous structure of xylem in grapevine (Schoch et al., 2004), $F_{d}$ has a quite even radial pattern and the error in its estimate is small. Moreover, no circumferential variations can be assumed in vines, owing to the small stem size, and usually only one set of TDP sensors is installed on each trunk ( $\mathrm{Lu}$ et al., 2003).

In vineyards, scaling up from plants to stand can be done by means of simple procedures: Trambouze et al. (1998) estimated field transpiration from mean transpiration of the sampled plants and the stand density. We applied the same method in both studies presented in this paper.

\subsection{Application of sap flow techniques in two ex- perimental sites}

The sap flow techniques previously described (Stem Heat Balance and Thermal Dissipation Probe) were applied in two vineyards, growing in Mediterranean environments. The experiments were carried out at two sites and transpiration measurements were tested against evapotranspiration measurements as detailed in the following.

\subsubsection{Experimental application - Stem Heat Bal-} ance. The study (De Lorenzi et al., 2002) was carried out in a 20 hectares vineyard in Southern Italy (Adelfia-Bari, $41^{\circ} \mathrm{N}, 17^{\circ} 54^{\prime} \mathrm{E}$ ), in a site with a semi-arid climate. Vines (cv. Italia) were trained with the overhead system, and the experiment was conducted in six days, when the vines were at veraison. The crop was irrigated the first day of experiment and the soil water content, as measured by the gravimetric method, decreased constantly over the experimental period (data not shown). Actual evapotranspiration $\left(E T_{a c t}\right)$ was measured by the Bowen Ratio/Energy Balance method (see Rana and Katerji, 2000). Temperature and humidity gradients were measured at 2.8 and 3.8 $\mathrm{m}$ above the ground; the fetch was over $300 \mathrm{~m}$ in all directions. All the measurements were 
recorded every $10 \mathrm{~s}$ and their 12-minute averages were stored in a data logger (CR10, Campbell Sci., UK). At the start of the measurement period six vines were selected and one shoot per vine was fitted with sap flow gauges (models SGB10 and SGB13, Dynamax Inc., USA), placed at the base of the shoot. Continuous sap flow measurements were recorded (every $10 \mathrm{~s}$ ) and stored (12-minute averages) through the six days. At the end of the measurement period, the gauged shoots were harvested and leaf area was measured with a leaf area meter (LI 3100, LICOR, USA), allowing the calculation of the mean area per leaf $\left(A_{\text {leaf }}, \mathrm{m}^{2}\right)$ and of total leaf area for each shoot $\left(A_{\text {shoot }}, \mathrm{m}^{2}\right)$. The basal diameter of each sampled shoot was also recorded and the shoots have been grouped in two classes according to diameter. A further sample of four vines was randomly selected, and the leaf area of the plant $\left(A_{\text {plant }}, \mathrm{m}^{2}\right)$ was estimated by $A_{\text {leaf }}$ and plant leaf number. Average leaf area of the four sample vines was $11.2 \mathrm{~m}^{2}$, and corresponding leaf area index 2.1.

The determination of area-average transpiration is described in the following. The average daily sap flow of the six shoots was computed $\left(T_{\text {shoot }}, \mathrm{kg} \mathrm{day}^{-1}\right)$ and, assuming that sap flow is proportional to leaf area, daily transpiration at plant level $\left(T_{\text {plant }}, \mathrm{kg}\right.$ day $\left.^{-1}\right)$ was estimated by means of $T_{\text {shoot }}$, the average leaf area of the gauged shoots $\left(A_{\text {shoot }}\right)$, and the plant leaf area $\left(A_{\text {plant }}, \mathrm{m}^{2}\right)$ :

$$
T_{\text {plant }}=T_{\text {shoot }} \frac{A_{\text {plant }}}{A_{\text {shoot }}}
$$

Through eq. (6) the daily plant transpiration of each sampled vine has been calculated. The average $T_{\text {plant }}$ of the four vines was then used to determine daily transpiration at field scale $\left(T_{\text {field }}, \mathrm{mm}\right.$ day $\left.^{-1}\right)$, taking into account plant spacing:

$$
T_{\text {feld }}=T_{\text {plant }} \frac{1}{S_{\text {plant }}}
$$

where $S_{\text {plant }}\left(\mathrm{m}^{2}\right)$ is the land surface area theoretically set to a plant.

2.4.2 Experimental application - Thermal Dissipation Probe. The study here presented was performed in a 2.5 ha winemaking vineyard, in a site with typical Mediterranean climate in Marsala (37 $67^{\circ} \mathrm{N}, 12^{\circ} 65^{\prime} \mathrm{E}$; Sicily Region, South- ern Italy) during spring and summer 2007. The vineyard was trained on "alberello" (bush vines) system. Three vines (cv Syrah) were equipped with TDP probes (UP GmbH, Germany), connected to a data logger (CR10X, Campbell Sci, UK). Measurements were taken every $10 \mathrm{~s}$, averaged and stored at 15 min intervals. Meteorological variables were measured by a standard agrometeorological station placed in the farm, $50 \mathrm{~m}$ away from the experimental field.

Evapotranspiration at stand level has been measured by means of the eddy covariance $(E C)$ technique. The tri-axial sonic anemometer measurements (USA-1, METEK, Germany), together with the fast analyser data of water vapour concentration (LI-Cor 7500, USA), were continuously recorded at a frequency $10 \mathrm{~Hz}$ by a dedicated personal computer. Evapotranspiration $(E T)$ values at hourly interval were calculated by a special resident software (Meteoflux, Servizi-Territorio, Milan, Italy). The EC variables were measured at $1 \mathrm{~m}$ height above the crop, in the centre of the experimental plot, and fetch length was adequate in all directions.

\section{Performance of the sap flow techniques and discussion}

In the following sap flow measurements are shown in shoots and plants, moreover the performances of the techniques are evaluated by comparison of sap flow data, scaled up to the field level, with evapotranspiration measurements by micrometeorological methods.

In the table grapes vineyard (overhead training, Apulia) the evapotranspiration was measured by the Bowen ratio method, while in the winemaking vineyard ("alberello" training, Sicily) evapotranspiration was measured by the eddy covariance method.

\subsection{Stem Heat Balance - Table grapes vineyard}

Figures $1 \mathrm{a}$ and $1 \mathrm{~b}$ show averaged flow rates on 21 and 24 July. The sap flow measurements are relative to two groups of shoots, having different basal diameter (13 and $11 \mathrm{~mm}$ ). The consistent differences in sap flow rates between the two groups correspond to the ranking of their measured leaf areas. Figures $1 \mathrm{c}$ and $1 \mathrm{~d}$ show, in the same two days, the sap flow rates per unit leaf area: flow rate of each shoot has been nor- 

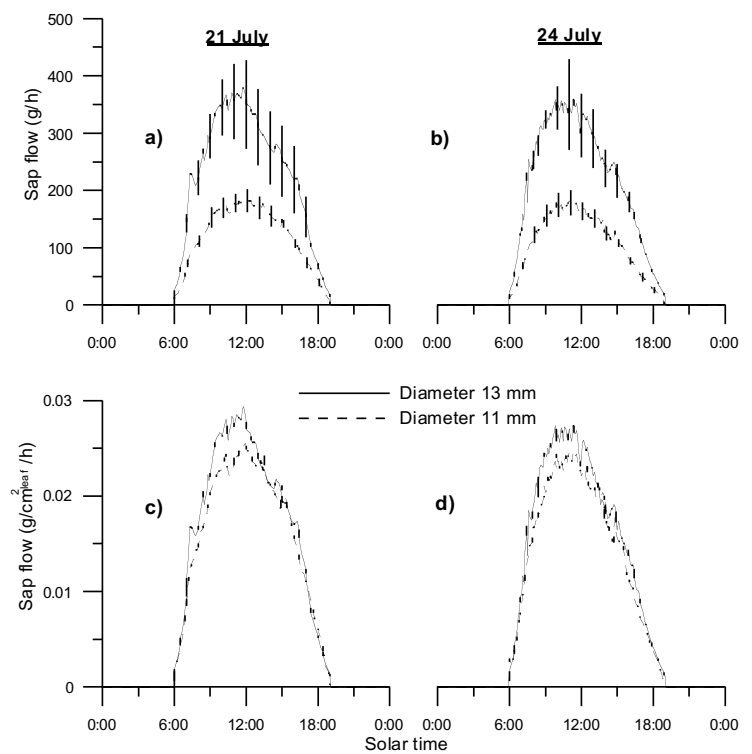

Figure 1. a) and b): diurnal courses of averaged sap flow rates, of two classes of shoots grouped according to their basal diameter for two summer days, bars indicate SE ( $\mathrm{n}=2$ and $\mathrm{n}=4$, respectively, in the 13 and $11 \mathrm{~mm}$ shoot diameter classes); c) and d) sap flow rates calculated per unit leaf area, in the same two days.

malised by its leaf area $\left(A_{\text {shoot }}\right)$, and the averages within groups have been calculated. The time series overlie one another almost exactly, showing that the differences in sap flow between the two groups are much smaller when flow rate is calculated per unit leaf area.

These results suggest that eq. (6) can provide reliable estimates of plant transpiration, and can be used, together with eq. (7), to estimate transpiration at field level. The trend in daily areaaverage transpiration is shown in figure 2 , for the 6-days period. Evaporative demand of the atmosphere $\left(E T_{0}\right)$ was very constant in the pe$\operatorname{riod}\left(E T_{0}=6.4 \mathrm{avg} \pm 0.1 \mathrm{sd} \mathrm{mm} \mathrm{day}{ }^{-1}\right)$. Area-average transpiration $\left(T_{\text {field }}\right)$ has a decreasing trend, in agreement with decreasing soil water availability; transpiration values vary from 4.7 $\mathrm{mm}$ day $^{-1}$ at the beginning of the period $(21 \mathrm{Ju}-$ ly) to $3.5 \mathrm{~mm}$ day $^{-1}$ on 26 July. Actual evapotranspiration $\left(E T_{a c t}\right)$, measured by the Bowen Ratio, is also reported in the figure; the trend of transpiration is very similar to the one of evapotranspiration. Soil evaporation, calculated as the difference between $E T_{\text {act }}$ and $T_{\text {field }}$, is around $1 \mathrm{~mm} \mathrm{day}^{-1}$, i.e. approximately $18 \%$ of actual evapotranspiration.

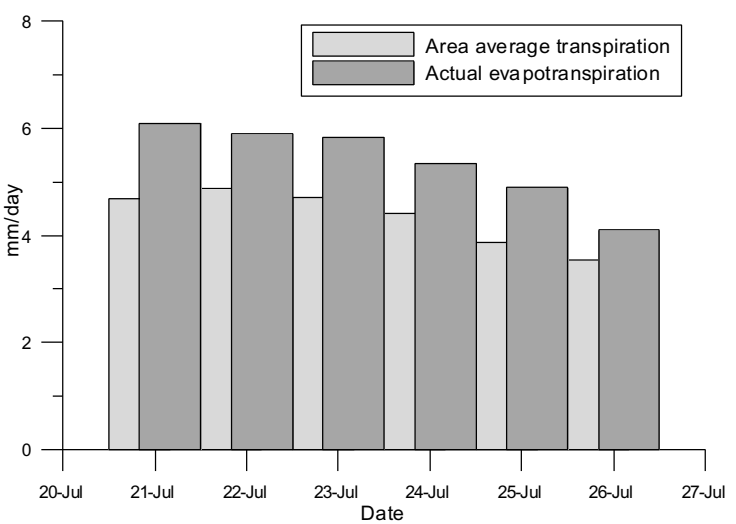

Figure 2. Daily values of transpiration measured by sap flow method at stand level, after scaling up, for 6 successive days during summer, and actual evapotranspiration measured by Bowen ratio.

\subsection{Thermal Dissipation Probe - Winemaking vineyard}

Figure 3 shows the hourly course of $\Delta T$ in two plants, of wind speed and air vapour pressure deficit in four days. Maximum temperature difference between the probes is reached at night, whereas, during the day, convective cooling caused by sap flow determines a reduction of $\Delta T$. During the nights of the second and third day (DOY 259, 260) the course of $\Delta T_{\max }$ is not regular due to the influence of unusual high

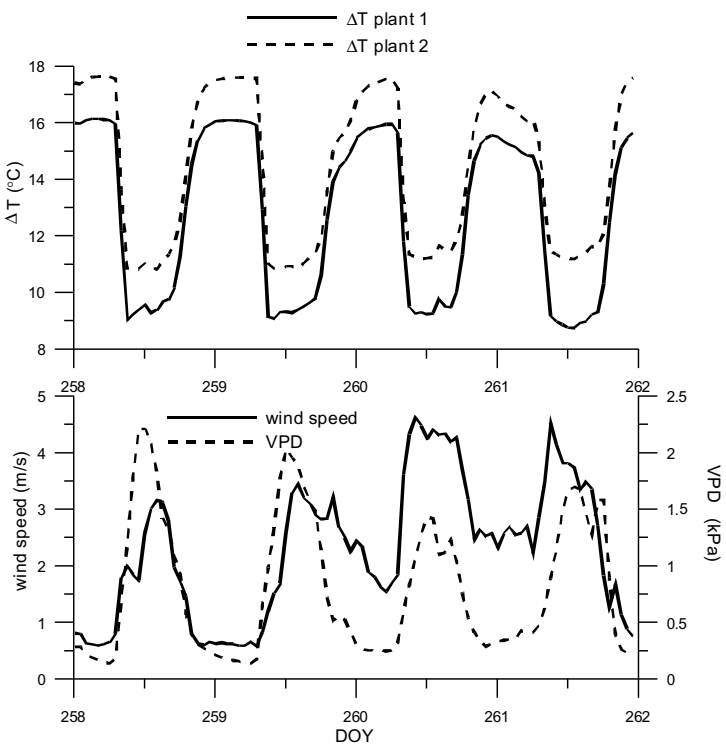

Figure 3. Hourly courses of $\Delta T$ measured by the TDP method in two plants, together with the wind speed and air vapour pressure deficit, measured in four successive days. 
wind speed, that may have caused some nocturnal transpiration flux. It was previously stated that the determination of $\Delta T_{\max }$ can be biased by night time fluxes; here in two nights the measured $\Delta T$ cannot be considered the $\Delta T_{\max }$, therefore in these two days the sap flow is calculated by averaging $\Delta T_{\max }$ of the two days preceding and the one following.

The possibility of measuring nocturnal flux of transpiration is particularly important for the evaluation of $\mathrm{O}_{3}$ deposition at daily scale. In fact, since $\mathrm{O}_{3}$ concentration can remain relatively high at night, mainly in hilly areas, the nocturnal larger than zero stomatal conductance can result in considerable ozone flux into plants (Musselman and Minnick, 2000). According to Massman (2004) nocturnal stomatal ozone uptake may account for about $15 \%$ of the cumulative effective ozone dose in vineyard.

The sap flow courses of the four days are shown in figure 4 , together with the course of incident solar radiation. The difference in sap flow rate between the two plants is due to the difference in their leaf area and the variability of flux among plants (Trambouze et al., 1998). The variation in daily courses were closely related to changes in solar radiation, except in the late afternoon, when the phase difference in the trends of radiation and VPD determines a slower decrease of sap flow with respect to solar radiation.

A preliminary estimate of daily transpiration

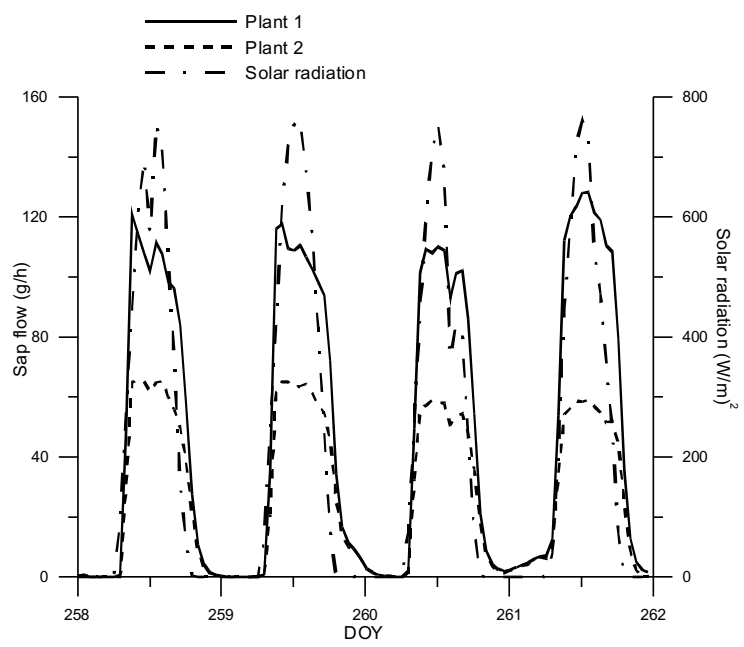

Figure 4. The sap flow daily courses measured by the TDP method in two plants, during 4 successive days in summer, together with the course of incident solar radiation.

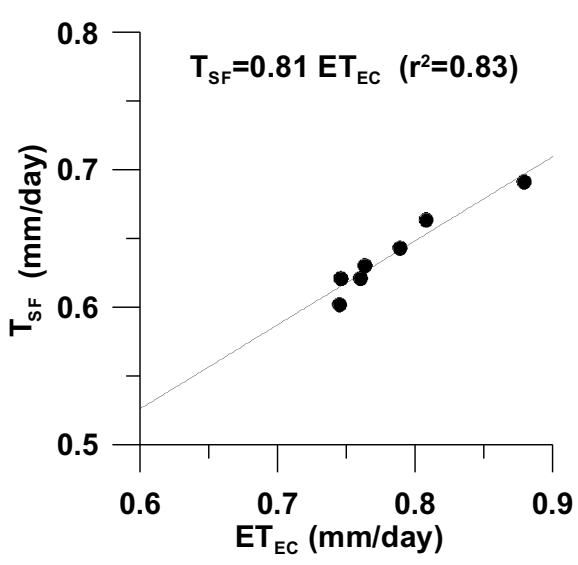

Figure 5. Comparison between transpiration measured by sap flow $\left(T_{S F}\right)$ and evapotranspiration measured by eddy covariance method $\left(E T_{E C}\right)$, at daily scale for 6 successive days during summer (27 July - 1 August)

at stand level was obtained by means of the arithmetic mean of values of sap flow of the sampled vines and by stand density. Results are shown in figure 5; here canopy transpiration $\left(T_{S F}\right)$ is compared with the vineyard evapotranspiration measured by the eddy covariance method.

There are few similar studies with which these results can be compared; moreover, due to the heterogeneity of plant development and vine growing conditions, water consumption values are difficult to compare. However, the observed values of daily transpiration agree with values measured by other authors. In a Texas vineyard, Heilman et al. (1996) measured a crop transpiration up to $4.2 \mathrm{~mm}^{-1}{ }^{-1}$ with a leaf area index of 1.4. For Southern France, Trambouze et al. $(1998,2001)$ report a vine transpiration of approximately $2.5 \mathrm{~mm} \mathrm{day}^{-1}$, at full vegetative growth (maximum leaf area index: 1.8).

The lower values of transpiration measured in the TDP study are comparable with those obtained by Lu et al. (2003) in a hot climate. In the two experiments, the observed values of soil evaporation are $18 \%$ and $19 \%$ of crop evapotranspiration, in the SHB and TDP studies, respectively. These values are well within the range of those measured by other authors. In fact, as it has been already stated, in sparse crops like vines the soil contribution to evaporation varies a lot. For instance, Heilman et al. (1996) showed that soil evaporation can account 
for $16-68 \%$ of evapotranspiration in a vineyard, when hedgerows density changes. Sene (1994) estimated, in a sparse vine crop under semi-arid conditions, soil evaporation values which accounted for $35 \%$ of total water consumption.

\section{Conclusions}

Sap flow methods are suited to applications requiring routine determinations of plant water use, moreover allow to study interrelationships between transpiration, hydraulic conductance in trees, and water potentials in the plant and the soil. These techniques can be applied in hydrological studies to extrapolate water-use rates of single trees to stand transpiration, overcoming some of the limitations found in the application of micrometeorological methods to discontinuous stands (Wullschleger et al., 1998).

Our results show that the Stem Heat Balance method can provide an accurate estimation of transpiration, and evaporative fluxes of vines and stand can be determined scaling up sap flow in shoots by means of leaf area and stand density. Transpiration measurements by Thermal Dissipation Probes are sensitive to nocturnal abiotic and biotic fluctuation in transpiration rates; sap fluxes can be extended to the whole stand with plant density. It should be noted that the main source of error in estimating transpiration in the stand is in the estimate of water use for individual trees and not in the spatial scaling-up process, as shown in Eucaliptus by Hatton et al. (1995); similarly, Giorio and Giorio (2003) have shown in olive that an accurate measurement by a single probe, calibrated by means of a proper statistical procedure, can be used to estimate the transpiration of an olive orchard in real time.

Sap flow methods are also useful in studies of plant responses to environmental conditions, where they are one of a suite of techniques employed in either the field or laboratory to measure changes in the water relations, growth and water use efficiency of plants resulting from, for example, new management practices, environmental stress or climate change.

In particular, major advances in quantifying ozone deposition in orchards have been made using above-canopy techniques, such as eddy covariance, that allow the direct measurement of ozone flux into crops. However, from abovecanopy flux measurements alone, it is impossible to distinguish between deposition through stomatal pores of trees and non-stomatal surfaces (Nunn et al., 2007). Therefore, there is a need to partition ozone fluxes into plant stomatal and non-stomatal components. This review shows that sap flow measurements provide a direct determination of transpiration from which we can infer canopy water vapour conductance and thus ozone uptake by trees. This represents a novel way to determine pollutant loading on stomatal surfaces of trees that is reliable and can be deployed in a multitude of environments (Kurpius et al., 2003).

\section{Acknowledgements}

The authors thank Nicola Martinelli, Michele Introna (CRA-SCA), Francesco Morga and Carlo Reina (University of Palermo, Italy) for the field and support work and Rosario Dell'Aquila (CNR-ISAFoM) for the laboratory assistance. The experimental studies here reported are a part of the project "CLIMESCO" (FISR D.D. n. 285 20.02.2006) and "FLUEN" (Italian National Research Council). The authors thank Azienda Foraci (Sicily, Italy) for hosting the study on Syrah vineyard.

\section{References}

Arya S.P. 2001. Introduction to micrometeorology. International Geophysics Series, Vol. 79, Academic Press, London, 420 pp.

Baker J.M., van Bavel C.H.M. 1987. Measurement of mass flow of water in the stem of herbaceous plant. Plant Cell Environment, 10:777-782.

Baker J.M., Nieber J.L. 1989. An analysis of the steadystate heat balance method for measuring sap flow in plants. Agricultural and Forest Meteorology, 48:93-109.

Bou Jaoudè M., Katerji N., Mastrorilli M., Rana G. 2008a. Analysis of the ozone effect on soybean in the Mediterranean region. I - The consequences on cropwater status. European Journal of Agronomy, 28(4): 508-518.

Bou Jaoudè M., Katerji N., Mastrorilli M., Rana G. 2008 b. Analysis of the ozone effect on soybean in the Mediterranean region. II - The consequences on growth, yield and water use efficiency. European Journal of Agronomy, 28(4):519-525.

Braun P., Schmid J. 1999. Sap flow measurements in grapevines (Vitis vinifera L.) 2. Granier measurements. Plant Soil, 215:47-55.

Clearwater M.J., Meinzer F.C., Andrade J.L., Goldstein G., Holbrook N.M. 1999. Potential errors in mea- 
surement of non-uniform sap flow using heat dissipation probes. Tree Physiology, 19:681-687.

Cohen Y., Takeuchi S., Nozaka J., Yano 1993. Accuracy of sap flow measurement using heat balance and heat pulse methods. Agronomy Journal, 85:1080-1086.

De Lorenzi F., Mingo A., Rana G. 2002. Diurnal variations of transpiration in a vineyard at different soil water availability. Atti Convegno inaugurale ISAFOM, 24-25 settembre 2002, Portici (NA).

Fagnano M. 1995. Tropospheric ozone concentration in Portici (Naples) in relation to meteorological parameters. Agricoltura Mediterranea, S.V.:390-394.

Fagnano M., Merola G. 2007. Ozone and water stress: effects on the behaviour of two white clover biotypes. Italian Journal of Agronomy, 2:3-12.

Fernández J.E., Green S.R., Caspari H.W., Diaz-Espejo A., Cuevas M.V. 2007. The use of sap flow measurements for scheduling irrigation in olive, apple and Asian pear trees and in grapevines. Plant and Soil, ISSN 1573-5036 (on line).

Ferretti M., Fagnano M., Amoriello T., Badiani M., Ballarin-Denti A., Buffoni A., Bussotti F., Castagna A., Cieslik S., Costantini A., De Marco A., Gerosa G., Lorenzini G., Manes F., Merola G., Nali C., Paoletti E., Petriccione B., Racalbuto S., Rana G., Ranieri A., Tagliaferri A., Vialetto G., Vitale M. 2006. Measuring, modelling and testing ozone exposure, flux and effects on vegetation in Southern Europe conditions What does not work? A review from Italy. Environmental Pollution, 146:648-658.

Forlani A., Merola G., Fagnano M. 2005. Ozone effects on vegetation in three different localities of Campania region. Fresenius Environmental Bulletin, 14:478-483.

Fumagalli I., Gimeno B.S., Velissariou D., De Temmerman L., Mills G. 2001. Evidence of ozone induced adverse effects on crops in the Mediterranean region. Atmospheric Environment, 35:2583-2587.

Giorio P., Giorio G. 2003. Sap flow of several olive trees estimated with the heat-pulse technique by continuous monitoring of a single gauge. Environmental Experimental Botany, 49:9-20.

Goldstein G.G., Andrade J.L., Meinzer F.C., Holbrook N.M., Cavelier J., Jackson P., Celis A. 1998. Stem water storage and diurnal patterns of water use in tropical forest canopy trees. Plant Cell Environment, 21:397-406.

Granier A. 1985. Une nouvelle méthode pour la mesure du flux de sève brute dans le tronc des arbres. Annales des Sciences Forestières, 42:81-88.

Granier A. 1987. Mesure du flux de sève brute dans le tronc du Douglas par une novelle méthode thermique. Annales des Sciences Forestières, 44:1-14.

Granier A., Biron P., Kostner B., Gay L. W., Najjar G. 1996. Comparisons of xylem sap flow and water vapour flux at the stand level and derivation of canopy conductance for scots pine. Theoretical and Applied Climatology, 53:115-122.
Grantz D.A., Zhang X.J., Massman W.J., Den Hartog G., Neumann H., Pederson J.R. 1995. Effects of stomatal conductance and surface wetness on ozone deposition in field-grown grape. Atmospheric Environment, 29:3199-3198.

Green S.R., McNaughton K.G., Clothier B.E. 1989. Observations of night-time water use by kiwifruit vines and apple trees. Agricultural and Forest Meteorology, 48:251-261.

Grime V.L., Morison J.I.L., Simmonds L.P. 1995. Including the heat storage term in sap flow measurements with the stem heat balance method. Agricultural and Forest Meteorology, 74:1-25.

Gutierrez M.V., Harrington R.A., Meinzer F.C., Fownes J.H. 1994. The effect of induced stem temperature gradients on transpiration estimates from the heat balance method in two tropical woody species. Tree Physiology, 14:179-190.

Hatton T.J., Moore S.J., Reece P.H. 1995. Estimating stand transpiration in a Eucalyptus populnea woodland with the heat pulse method: measurement errors and sampling strategies. Tree Physiology, 15:219-227.

Heilman J.L., McInnes K.J., Gesch R.W., Lascano R.J., Savage M.J. 1996. Effects of trellising on the energy balance of a vineyard. Agricultural and Forest Meteorology, 81:79-93.

Kjelgaard J.F., Stockle C.O., Black R.A., Campbell G.S. 1997. Measuring sap flow with the heat balance approach using constant and variable heat inputs. Agricultural and Forest Meteorology, 85:239-250.

Köstner B., Granier A., Cermák J. 1998. Sapflow measurements in forest stands: methods and uncertainties. Annales des Sciences Forestières, 55:13-27.

Kurpius M.R., Panek J.A., Nikolov N.T., McKay M., Goldstein A.H. 2003. Partitioning of water flux in a Sierra Nevada ponderosa pine plantation. Agricultural and Forest Meteorology, 117:173-192.

Lu P. 1997. A direct method for estimating the average sap flux density using a modified Granier measuring system. Australian Journal of Plant Physiology, 24: 701-705.

Lu P., Yunusa I.A.M., Walker R.R., Muller W.J. 2003. Regulation of canopy conductance and transpiration and their modelling in irrigated grapevines. Functional Plant Biology, 30:689-698.

Lu P., Urban L., Ping Z. 2004. Granier's Thermal Dissipation Probe (TDP) Method for Measuring Sap Flow in Trees: Theory and Practice. Acta Botanica Sinica, 46:631-646.

Massman W.J. 2004. Toward an ozone standard to protect vegetation based on effective dose: a review of deposition resistances and possible metric. Atmospheric Environment, 38:2323-2337.

Mitic C.M., Massman W.J., Schuepp P.H., Collett Jr J.L. 1999. Structural analysis and flux association of $\mathrm{CO}_{2}$ and $\mathrm{H}_{2} \mathrm{O}$, heat and ozone over cotton and grape canopies. Atmospheric Environment, 33:1159-1173. 
Musselman R.C., Massman W.J. 1999. Ozone flux to vegetation and its relationship to plant response and ambient air quality standards. Atmospheric Environment, 33:65-73.

Musselman R.C., Minnick T.J. 2000. Nocturnal stomatal conductance and ambient air quality standards for ozone. Atmospheric Environment, 34:719-733.

Musselman R.C., Lefohn A.S., Massman W.I., Heath R.L. 2006. A critical review and analysis of the use of exposure- and flux-based ozone indices for predicting vegetation effects. Atmospheric Environment, 40:1869-1888.

Nadezhdina N., Nadezhdin V., Ferreira M.I., Pitacco A. 2007. Natural variability of sap flow in trunks and branches of mature olive trees. Tree Physiology, 27:105-113.

Nunn A.J., Wieser G., Metzger U., Löw M., Wipfler P., Häberle K.H., Matyssek R. 2007. Exemplifying whole-plant ozone uptake in adult forest trees of contrasting species and site conditions. Environmental Pollution, 146:629-639.

Postiglione L., Fagnano M., Merola G. 2000. Response to ambient ozone of two white clover (Trifolium repens L., cv. Regal) clones, one resistant and one sensitive, grown in a Mediterranean environment. Environmental Pollution, 109:525-31.

Rana G., Katerji N. 2000. Measurement and estimation of actual evapotranspiration in the field under Mediterranean climate: a review. European Journal of Agronomy, 13:125-153.

Rana G., Katerji N., De Lorenzi F. 2005. Measurement and modelling of evapotranspiration of irrigated citrus orchard under Mediterranean conditions. Agricultural and Forest Meteorology, 128:199-209.

Sakuratani T. 1981. A heat balance method for measuring water flux in the stem of intact plants. Journal of Agricultural Meteorology, 37:9-17.

Sandermann H. Jr. 1996. Ozone and plant health. Annual Review Phytopathology, 34:347-366.

Schoch W., Heller I., Schweingruber F.H., Kienast F. 2004. Wood anatomy of central European Species. Online version: www.woodanatomy.ch

Sene K.J. 1994. Parametrisation for energy transfers from a sparse vine crop. Agricultural and Forest Meteorology, 71:1-18.
Shertz R.D., Kender W.D., Musselman R.D. 1980. Effects of ozone and sulfur dioxide on grapevines. Scientia Horticulture, 13:37-45.

Smith D.M., Allen S.J. 1996. Measurement of sap flow in plant stems. Journal of Experimental Botany, 47:1833-1844.

Snyder K.A., Richards J.H., Donovan L.A. 2003. Nighttime conductance in $\mathrm{C}_{3}$ and $\mathrm{C}_{4}$ species: do plants lose water at night? Journal Experimental Botany, 54:861865.

Soja G., Eid M., Gangl H., Redl R. 1997. Ozone sensitivity of grapevine (Vitis vinifera L.): evidence for a memory effect in a perennial crop plant? Phyton, 37:265-270.

Tognetti R., d'Andria R., Morelli G., Calandrelli D., Fragnito F. 2004. Irrigation effects on daily and seasonal variations of trunk sap flow and leaf water relations in olive trees. Plant and Soil, 263:249-264.

Trambouze W., Bertuzzi P., Voltz M. 1998. Comparison of methods for estimating actual evapotranspiration in a row-cropped vineyard. Agricultural and Forest Meteorology, 91:193-208.

Trambouze W., Voltz M. 2001. Measurement and modelling of the transpiration of a Mediterranean vineyard. Agricultural and Forest Meteorology, 107:153166.

Weinstein L.H. 1984. Effects of air pollution on grapevines. Vitis, 23:274-303.

Wieser G. Matyssek R., Kostner B., Obehruber W. 2003. Quantifying ozone uptake at the canopy level of spruce, pine and larch trees at the alpine timberline: an approach based on sap flow measurement. Environmental Pollution, 126:5-8.

Wullschleger S.D., Meinzer F.C., Vertessy R.A. 1998. A review of whole-plant water studies in trees. Tree Physiology, 18:499-512.

Yunusa I.A.M., Walker R.R., Lu P. 2004. Evapotranspiration components from energy balance, sapflow and microlysimetry techniques for an irrigated vineyard in inland Australia. Agricultural and Forest Meteorology, 127:93-107

Zhang H., Simmonds L.P., Morison J.I.L., Payne D. 1997. Estimation of transpiration by single trees: comparison of sap flow measurements with a combination equation. Agricultural and Forest Meteorology, 87:155-169. 